\title{
The Significance of Common Currency to the Success of Economic Integration
}

\author{
Oladele Omosegbon \\ Indiana Wesleyan University
}

All of the Regional Economic Communities, REC, in Africa, including the Economic Community of West African States, ECOWAS, have been struggling with the creation of a common currency since inception. But common currency is a necessary condition for an economic community to exist. Without economic union, Africans have been in currency unions before. The ascendancy of Africa in the world stage and the main path to avoid a stunted development as revealed in its logistic population growth, are going to depend on the size of its economy and in the use of a common currency.

\section{INTRODUCTION}

The Economic Community of West African States, as an example of regional economic community in Africa, REC, has been struggling with the creation of a common currency since 2003, when the Eco was scheduled to circulate. We have witnessed several postponements since then, the latest being from the set date of 2015 to 2020. All agents desire a united West Africa, just like the African Union and its members states desire a developed, prosperous and united Africa. But if asked about using a common currency, many decision makers run into uncertainties and ambiguities. For many policy makers, the decision of whether to accept a common currency is a big irritation and an embarrassing nuisance.

Academics tend to be intellectually dishonest about the importance of money in an economic community. On the one hand, some display remarkable niceties and dexterity via, for instance, the optimal currency area research, of the near impossibility and incongruence of a common currency in most African regional economic communities. On the other hand, others are quick to go into the exegesis of economic integration in, inter alia, stating that economic unions tend to ensure the free flow of human and material resources among cooperating nations, and hence, countries uniting tend to benefit. But this is intellectually dishonest, because only when common money is instituted can there be the kind of benefits everyone is talking about regarding economic union and cooperation among nations. Common currency is a necessary condition for an economic community to exist but not sufficient. It is sufficient when there is political unification. This fact that common currency is only a necessary condition for an economic community to operate gives some flexibility for ECOWAS and indeed other regional economic communities in Africa to establish a functional common currency that will kick start a rather uninspiring, invariant economic fortune, since the colonizing countries of Europe left Africa more than fifty years ago.

It is proposed that the mere act of adopting a common currency is itself a signal to a promising and prosperous economic union bringing to fruition the role money plays in traditional individual economies throughout the world and throughout time. But the new opportunities in the expanded multistate economy 
bring added platforms for money to play an accelerated and a deepening function in not just banking and financial development but also in the overall living of the unionizing peoples. This is the essence of economic integration - economic and monetary union which culminates from the movements from free trade area through customs union to monetary union.

\section{MONEY NOT THE ROOT OF ALL EVIL BUT AN INDISPENSABELE FRIEND}

In the grand scheme of things, money is sometimes seen as a stumbling block to wellbeing. We all have examples of clichés like money is the root of all evil, money does not buy happiness and the like. One thing that is going on here is the confusion of the role of money in affecting welfare and whether money enhances or hinders wellbeing. One area this is hotly discussed is in the attempt to compare people and their welfare across the world. We tend to measure happiness and call some citizens the happiest or the least happy in the world.

FIGURE 1

MONEY AND HAPPINESS

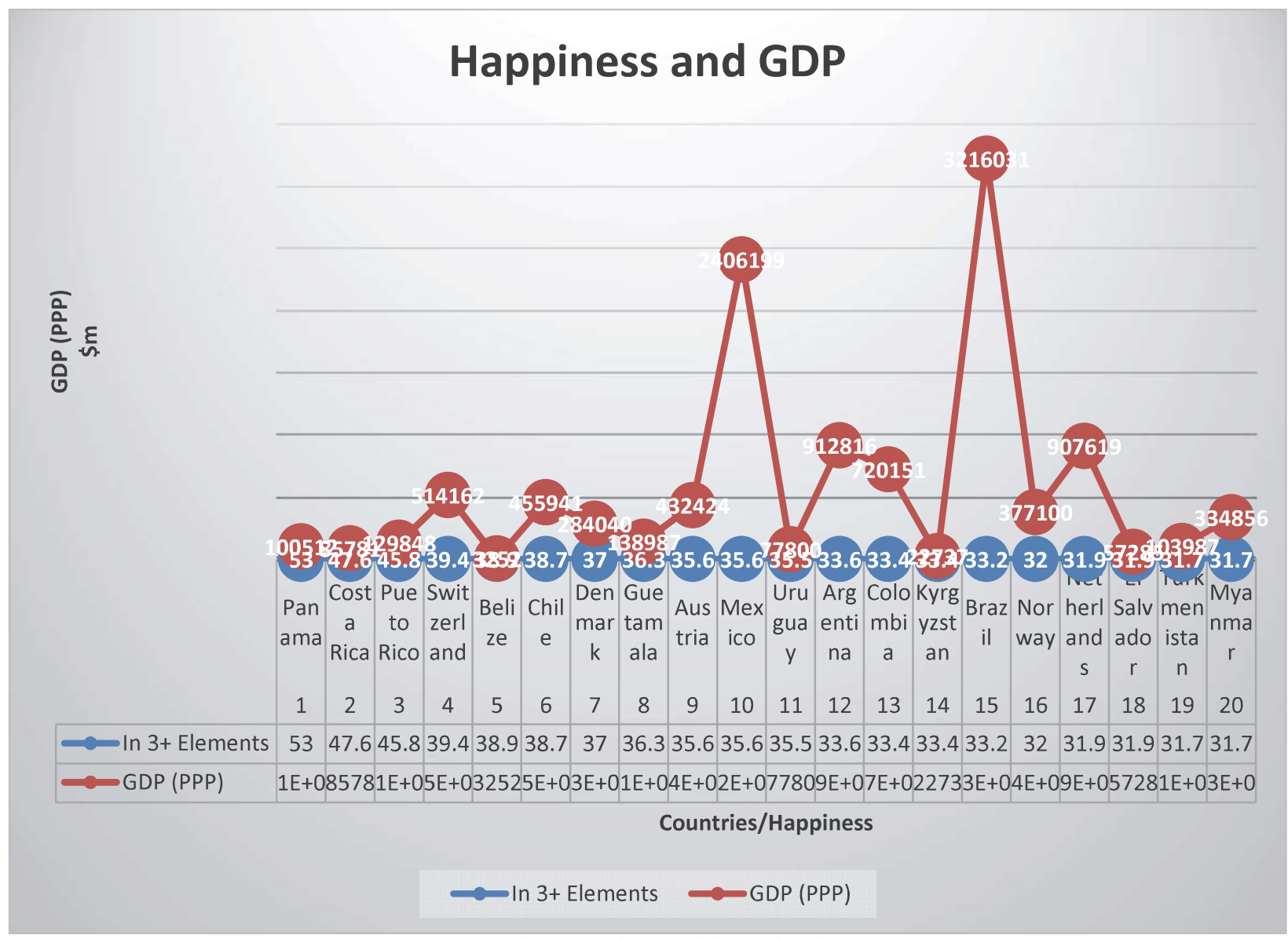

Source: Rettner, R. (2015). Live Science; CIA (2018) The World Factbook.

20 happiest countries and their GDP (2017). Happiness in \%. Survey of 146,000 people Striving in 3 or more areas of, sense of purpose, social relationships, financial situations, community involvement and physical health. 
At the individual level, money helps to create freedom; the freedom to move and the freedom to live. At the firm level, money dictates the flow of resources and of the exercise of preferences by consumers and producers. Read these about money:

1. "Money dictates the flow of human living in the modern world. Without money, life is often difficult and painful... It helps to create freedom. I've seen both want and abundance of money in life, and I can say one of the most depressing times in life was when I was without money" (Zach, O, quoted in Omosegbon, 2017).

2. "Money is a non-negotiable, indispensable commodity in every person's life. The possession of money is itself a resource and the usage of it can help to acquire resources. All the things we use in our lives have monetary value, whether directly or indirectly. Money's power is indisputable after the power of faith or self-belief in human life" (Zach, 2014, Section 1).

3. "With money, you can often rule today's materialistic world. If you have enough money, poverty will never approach you. Contrary to what most people think, it is not money or the love of money which is the root of evil-it is greed, a love of power and authority, poverty, and a fear of want which are often the roots of evil in this world. Money is just a humble agent in this scenario, because money helps to create power and authority. Money helps to eliminate poverty. Money helps to eliminate wants in life, especially if the wants are related to commercial and even human interaction, as most human interaction in the modern world is now commercialized" (Zach, 2014, Section 3).

Flowing from these, one would think that in an economic union, the leaders would make the provision of money a priority especially since, as we claim, it is a necessary condition for an economic union to occur.

Money is the basis of intertemporal, intergenerational and international transfer of resources. At the level of a nation and hence an economic community, common currency facilitates the competitive power of the community in trade and in the bidirectional flow of assets. Common currency is necessary for an economic union and can be created with a lot less difficulty than our African leaders have made it to look so far. After all, without economic union, Africans have been in currency unions before. In the British West Africa, the pound, in Eastern Africa, the East African Shilling and since colonial times, we have been witnessing the many perennial facets of the CFA franc.

\section{STYLIZED IMPEDIMENTS TO THE USE OF COMMON CURRENCY}

Following the example of the European Union's strict criteria employed in preparing for the launching of the Euro in the 1992 Maastricht Treaty, African countries, including those in ECOWAS, now adopt what are known as Convergence Criteria to gauge, among other things, the readiness of the community in adopting a common currency. For ECOWAS, these are a set of ten (four primary and six secondary) conditions members are expected to meet in order to be assessed ready for the adoption of a common currency. A more recent listing and assessment of these criteria is given in Saka, Onafowokan, and Adebayo (2015, Table 1). It is clear that these criteria have not been met, at least, that is the reason given for the now more than five postponements of dates of circulation of the Eco, the latest postponement being in 2016, when the Committee of Governors of the Central Banks in ECOWAS announced a new date of 2020 (Premium Times, July 4, 2016).

It is believed that the real reason the Eco is not circulating in West Africa is due to two factors. The first is the time inconsistency in the decision making by the heads of governments of member states (Omosegbon, 2017). Secondly, it is now clear that the CFA, which has been circulating in much of Africa since 1945 is of questionable benefit to the long-term development of the continent. The two zones of CFA, which are in, largely West and Central Africa, are tied to the fixed rates based on historical agreement between France and its mostly ex colonies. It is striking the value of CFA is not affected by economic conditions in the African countries using it. Even when there are big swings in the values of cotton and cocoa, the primary exports in these CFA countries, or when these countries go into tail spins of political and election instabilities, the exchange rate of their currency, the CFA, is relatively unaffected. 
Clearly, such a system offers the elite and the middle class in the CFA countries cheap foreign goods and leave the farmers and average consumers with low revenues, since exports are relatively expensive while there is a worldwide decline in demand for these exports at the same time.

A common currency, in an economic union, takes the place and the importance of money in a national economy. In international trade, it eliminates all the encumbrances of multiple currencies, transaction costs and the vexing issues of triangular currency convertibility.

With common currency, consumers are able to make a more direct comparison of the value of goods traded. It therefore follows that the ability to directly compare value and price of goods traded allows several markets to come together forming homogeneous structure based on one common unit of account. Adoption of a single currency exposes domestic markets to foreign markets thereby increasing competition between member countries and changes the competitiveness of national industries... (Saka, O., Onafowokan, A., and Adebayo, A. (2015, p.233).

\section{AFRICA AND AFRICANS: A RACE AGAINST TIME}

For ECOWAS, forty-three years on, the dream of a common union with a common currency and integrated economies is yet to be realized. While it is generally agreed that African economies are underdeveloped or are developing, it is time to start thinking what the end game is likely to be. The time is not infinite for Africa to make its mark in the world. These economies cannot remain developing for the next fifty years. If they do, it would be a disaster for their populations. Both the economies and the demographic characteristics would be stunted or dwarfed. This is because, whereas it is a good thing that the median age in almost all African countries are below or around 20 years, compared to the more advanced societies of North America, Europe, Japan and Australia where the median age in many of the countries is around 40 years or more, it is questionable whether the huge increases in population expected in these African countries in the coming years would not pose serious problems, if there are no concomitant advancements in material living. Africa is already predicted to be home to most of the world's population by 2100 as shown in Tables 1 and 2 .

TABLE 1

TEN MOST POPULOUS COUNTRIES IN THE WORLD BY 2100

1. India $1.66 \mathrm{bn} 2$. China $1.004 \mathrm{bn} 3$. Nigeria $752 \mathrm{~m} \mathrm{4.} \mathrm{US} 450 \mathrm{~m}$ 5. DR Congo $389 \mathrm{~m}$

6. Pakistan $364 \mathrm{~m}$ 7. Indonesia $314 \mathrm{~m} \mathrm{8}$. Tanzania 299m 9. Ethiopia $243 \mathrm{~m} \mathrm{10.} \mathrm{Niger} 209 \mathrm{~m}$

Source: Indy 100 (2017)

TABLE 2

AFRICAN COUNTRIES AMONG THE MOST POPULOUS

$\begin{array}{lllll} & & \text { Population(m) } & \text { Current } & \text { Pop. } \\ \text { Country } & \text { MD Age 2017 } & 2100 & \text { Population } & \text { Rate } \\ \text { Nigeria } & 18.3 & 752247 & 182200 & 2.7 \\ \text { Congo (DRC) } & 18.4 & 388733 & 77270 & 3.2 \\ \text { Tanzania } & 17.6 & 299133 & 53470 & 3.2 \\ \text { Ethiopia } & 17.8 & 242644 & 99390 & 2.5 \\ \text { Niger } & 15.3 & 209334 & 19900 & 4.1\end{array}$

Source: www.internetworldstats.com/stats8.htm

112 Journal of Applied Business and Economics Vol. 20(5) 2018 
The troubling part of this is that by 2100 (projected populations for 2100 are used as the carrying capacities in this study), these economies are not predicted to be near the best in the world. This is saying that an underdeveloped economy combined with huge population, spells trouble. In fact, following the work below, if there is no major intervention, particularly the merging into bigger and more prosperous economies, African societies and African populations would be dwarfed by 2100 . In the PwC analysis for projections to 2050, no single African country makes the list of the top 10 economies (https://www.pwc.com). An economic union with a flourishing common currency promises to confer a real importance to African regional economic communities and places each to compete as a strong trading bloc in the world for years to come. In order to explore the interplay between the economy and population growth, we next analyze the implications of rapid population increases on the welfare of Africans.

\section{A PRIMER IN POPULATION GROWTH}

Evolutionary biologists and ecologists often propose that the growth of populations of all sorts follows an exponential growth process. But since we all know by now that populations cannot grow monotonically, the logistic model is seen as a better approximation to the growth of populations (Study.com, 2017). This way the growth of populations depends on the size of the population, and the net birth rate. In what follows, it is assumed that population change follows a logistic growth process which can be approximated by

$$
\frac{d N}{d t}=k N\left(1-\frac{N}{K}\right) \text { or } \frac{d N}{d t}=k N\left(\frac{K-N}{K}\right)
$$

and

$\mathrm{N}(\mathrm{t})$ represents population at time $\mathrm{t}$, the initial period is $\mathrm{N}(0) ; \mathrm{t}=0,1,2 .$. , when the population grows or decays.

$\mathrm{k}$ is the relative or intrinsic rate of increase of the population.

$\mathrm{K}$ is the carrying capacity i.e. maximum population that is supportable by available resources, all else constant.

FIGURE 2

WORLD POPULATION GROWTH SINCE 1800

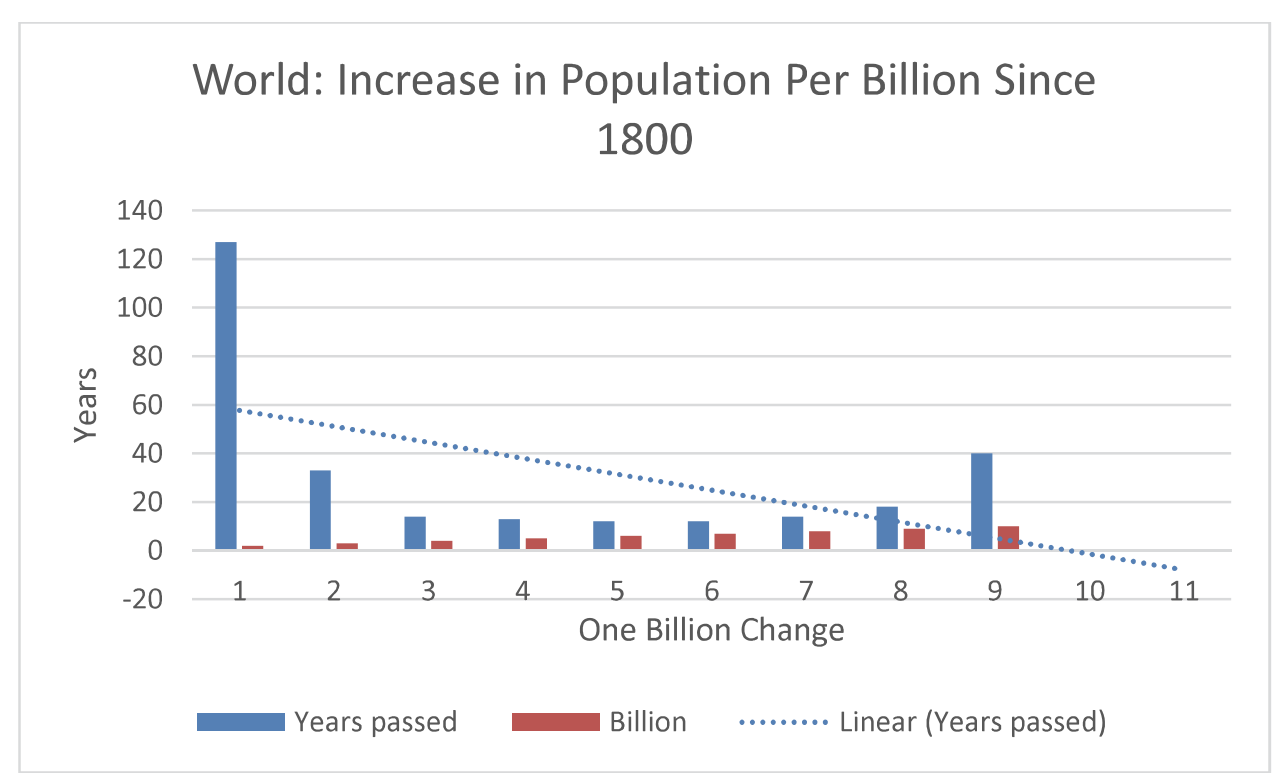

Source: United Nations Population Fund, UNPF. 
Shows years it takes to increase world population by one billion since 1800 . A clear negative linear relationship: a tendency toward exponential growth.

\section{FIGURE 3}

YEARS TO INCREASE WORLD POPULATION BY 1 BILLION SINCE 1800 (PERIOD 1)

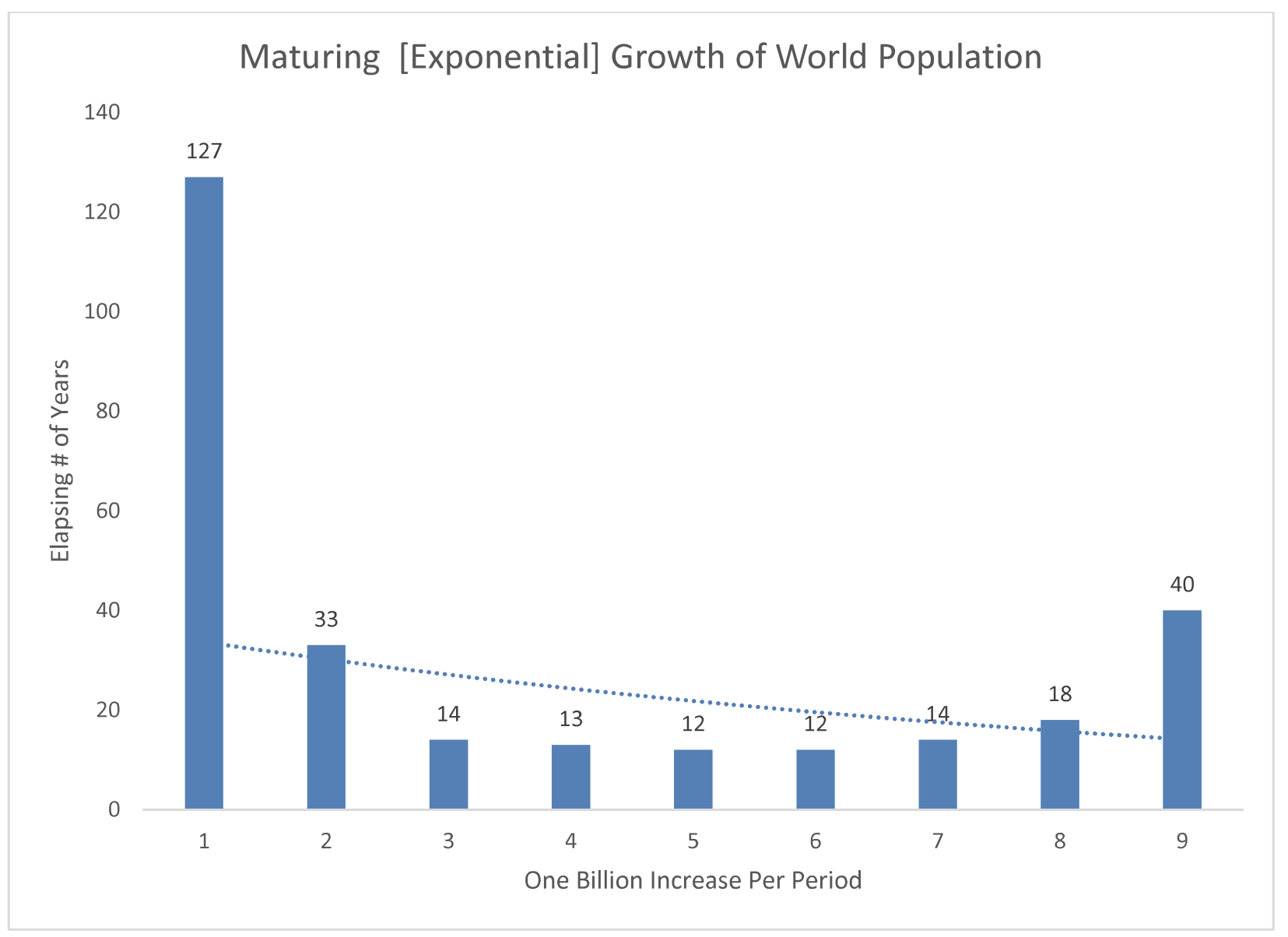

Source: United Nations Population Fund. Data retrieved from https://en.wikipedia.org/wiki/Population growth

The exponential trend line turns logistic at advanced stages: it now takes 14,18 and 40 years to increase by one billion instead of 12 years, implying little room for rapid human development for matured population demographics without corresponding economic advancement. 
FIGURE 4

POPULATION GROWTH AND DENSITY DEPENDENCY IN THE U.S.

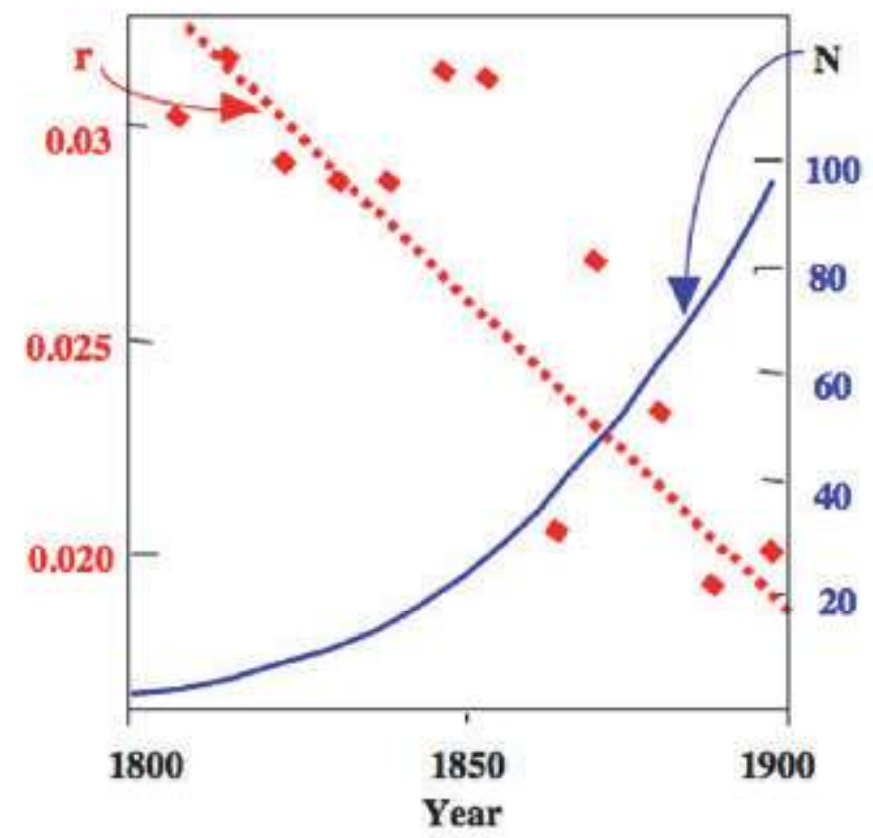

Source: Vandermeer, J. (2010), Figure 4

Tracks the increases in the U.S. population in the $19^{\text {th }}$ century, even though, the intrinsic rate of increase, our $r$, reveals a clear tendency of decline arising from higher U.S. population density.

Returning to equation 1 earlier, we can solve for the population that is consistent with the carrying capacity at any time $t$, given the initial population value $\mathrm{N}_{0}$.Vandermeer (2010), equations $1-8$; Snider and Brimlow (2013).

$$
\mathrm{N}(\mathrm{t})=\frac{K}{1+A e-k t} \text { and } A=\frac{K-N o}{N o}
$$

The results for African countries, those that make the list of ten most populous countries, are shown below. 
FIGURE 5

CURRENT GROWTH AND CARRYING CAPACITIES IN AFRICA

\section{Africa's Carrying Capacities with Current Rates of Growth: Most Populous Countries}

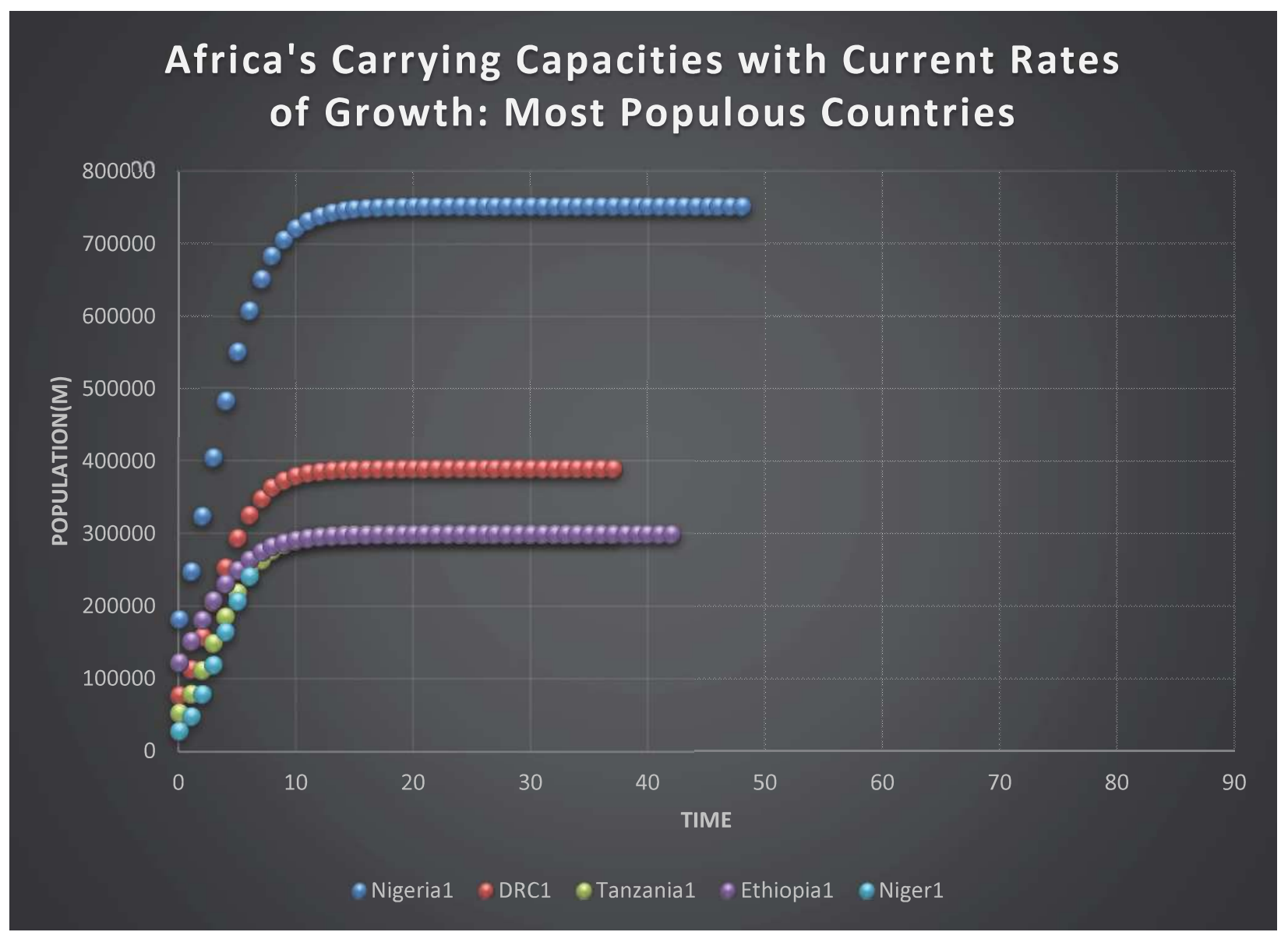

Source: Logistic equations estimated from data at www.internetworldstats.com/stats8.htm.

Shows current population growth rates in Africa's most populous countries and resource sustainability None of the countries are able to make it to its carrying capacity growing at current population rates. 


\section{FIGURE 6 \\ AFRICA'S POPULATION GROWTH UNDER REDUCED $k$}

\section{Africa's Carrying Capacities with Reduced Rates of Population Growth}

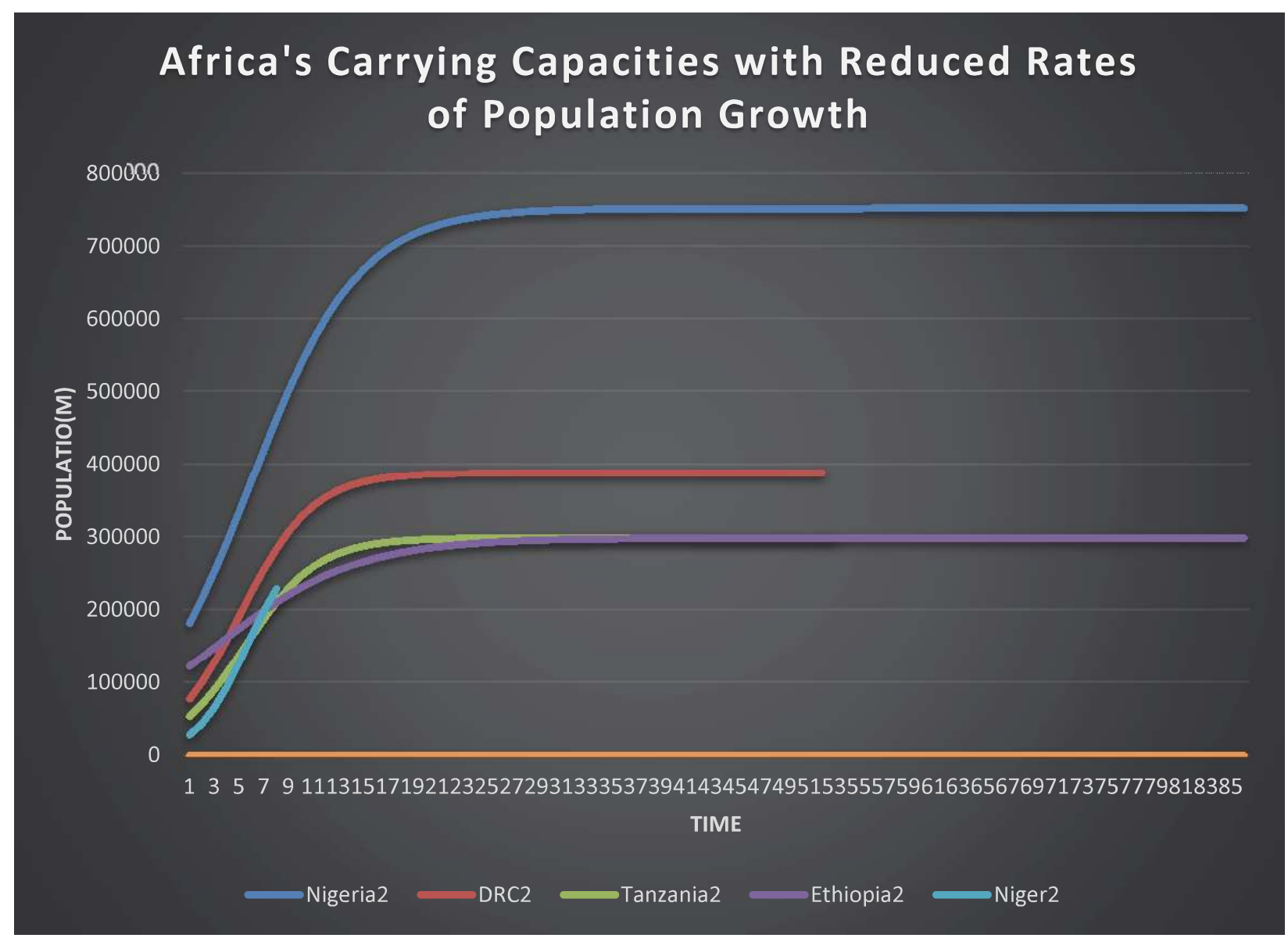

Source: Logistic equations estimated from data at www.internetworldstats.com/stats8.htm.

Shows population growth in Africa's most populous countries when current rates are reduced by 1 .

Figure 6 is drawn assuming intrinsic rates of growth are reasonably curtailed by subtracting 1 from its current rates drawn in Figure 5 above. Because of high intrinsic rates of growth in Tanzania and Niger, none of them is able to postpone the real possibility of dwarfed development that comes with population density. On the other hand, if Ethiopia and Nigeria are able to keep current rates of growth much lower, reducing its rate by $1 \%$ each, in the absence of faster economic performance than is seen now, it appears that both are able to grow to their estimated carrying capacity at the end of the period, which is $2100-$ period 85. Notice that the difference between the pair of Niger and Tanzania and the pair of Nigeria and Ethiopia is in the interaction or dependency between relative rate of growth and population density, our $\mathrm{k}$ in equations 1 and 2. $\mathrm{k}$ is high for Niger/Tanzania and low for Nigeria/Ethiopia.

One plausible way to avoid a stunted demographic maturation is by unionizing. That is, by the fruition of the regional economic efforts, signified by the circulation and usage of a common currency to serve as the anchor of trade and lubricant of the constituting economies; in the case of ECOWAS, the now 16-member countries with the recent admission of the Kingdom of Morocco. 


\section{SUMMARY AND CONCLUSION}

A common currency is a necessary condition for the realization of the benefits of integration. Common money is the signification of an economic community and a united and developed people. The importance of African economies in global trade is not going to be judged by the power of each country's individual economy, for there is none, or the stability provided by the benevolence of a colonial master in the use of, for instance, the CFA franc, but in the actual share of the proposed Eco, for ECOWAS countries, in world official foreign reserves, its liquidity in international trade and its role as a competitor against existing reserve currencies like the U.S. dollar, the Euro, the Pound Sterling, the Yen and the Yuan. The ascendancy of ECOWAS countries in the world stage is going to depend on the size of its union economy and in the use of its currency as an intervention and an anchor money. This is only possible if ECOWAS as an economic community comes to full fruition with a flourishing common money, commanding a widely acceptable internal purchasing power. But it is also a sobering manifestation that the only way to avoid a dwarfed or stunted development is for African countries to complete their economic integration efforts of which the circulation of a common currency is a necessary condition.

\section{REFERENCES}

Amadou, N. (2016, March). The Role of the CFA Franc in the Economic Integration of the West Africa Region. Retrieved from Brookings.edu: https://www.brookings.edu/wpcontent/uploads/2016/03/CFA-FRANC-WAEMU-PRESENTATION-DAKAR-ASYNOVEMBER-2015-v2.pdf

Asongu, S., Nwachukwu, J., \& Tchamyou, V. (2015). A Literature Survey on Proposed African Monetary Unions. Yaoundé, Cameroon: African Governance and Development Institute. Retrieved May 29, 2017 from Journal of Economic Surveys, DOI: 10.1111/joes.12174.

Bakoup, F. \& Ndoye, D. (2016). Why and When to Introduce a Single Currency in ECOWAS. Africa Economic Brief, 7(1). Retrieved from https://www.afdb.org/fileadmin/uploads/afdb/Documents/Publications/AEB_Vol_7_Issue_1_201 6_Why_and_when_to_introduce_a_single_currency_in_ECOWAS.pdf

CIA (2018) The World Factbook. Retrieved from https://www.cia.gov/library/publications/the-worldfactbook/rankorder/2004rank.html

Dunlop, C.A. \& Radaelli, C.M. (2016, June). Policy Learning in the Eurozone Crisis: Modes, Power and Functionality. Policy Sciences, 49(2), pp. 107-124. doi:DOI: 10.1007/s11077-015-9236-7

Gulde, A. (2008). Overview. Retrieved from IMF.org: http://www.imf.org/external/pubs/nft/books/2008/cfazone/chap1.pdf

Indy 100 (2017). Retrieved from https://www.indy100.com/article/these-will-be-the-10-mostpopulated countries-on-earth-in-2100--bkyViNS8Vx

Internet World Stats (2017). Retrieved from www.internetworldstats.com/stats8.htm

McLeay, M., Radia, A. and Thomas, R. (2014). Money in the modern economy: an introduction. Quarterly Bulletin 2014 Q1, Bank of England. Retrieved from http://www.bankofengland.co.uk/publications/Documents/quarterlybulletin/2014/qb14q1 prer eleasemoneyintro.pdf

Omosegbon, O. (2017). Lucas critique, time inconsistency, and economic integration in Africa. African Finance and Economics Association at the American Economic Association Annual Meetings, Chicago, Illinois, January 6-8, 2017.

Papademos, L (2006). The global importance of the euro. European Central Bank. Retrieved from http://www.ecb.europa.eu/press/key/date/2006/html/sp061117.en.html

Premium Times (July 4, 2016). Single currency for West African postponed to 2020. Retrieved from http://www.premiumtimesng.com/business/165081-single-currency-for-west-africapostponed-to-2020.html 
PwC (2017). The World in 2050. Retrieved from https://www.pwc.com/gx/en/issues/economy/the-world-in-2050.html

Rettner, R (2015). Live Science. The world's happiest countries (the list). Retrieved from http://www.livescience.com/51327-happiest-countries-list.html

Saka, O., Onafowokan, A., and Adebayo, A. (2015). Analysis of convergence criteria in a proposed monetary union: A study of the Economic Community of West African States.International Journal of Economics and Financial Issues Vol. 5, No. 1, 2015, pp.230-239

Scheller, H. (2006). European Central Bank: History, Role, and Functions. (2nd Revised edition). Frankfurt, Germany. Retrieved from https://www.ecb.europa.eu/pub/pdf/other/ecbhistoryrolefunctions2006en.pdf

Snider, S. and Brimlow, J. (2013). An introduction to population growth. Nature Education Knowledge 4(4):3

Study.com (2017). Logistic population growth: Equation, definition and graph. Retrieved from study.com/academy

Sy, A. \& Sow, M. (2016, March 15). Four questions on the state of the West African Economic and Monetary Union and Implications for Other Regional Economic Communities. Retrieved from Brookings: https://www.brookings.edu/blog/africa-in-focus/2016/03/15/four-questions-on-thestate-of-the-west-african-economic-and-monetary-union-and-implications-for-other-regionaleconomic-communities/

Vandermeer, J. (2010). How populations grow: The Exponential and Logistic equations. Nature Education Knowledge 3(10):15

WAMA.org. (2008, June). Review of ECOWAS Exchange Rate Mechanism. Retrieved from WAMA.org: http://amao-wama.org/wp-content/uploads/2016/10/Exchange-rate-mechanism.pdf

WAMA.org. (2017). Review of ECOWAS Exchange Rate Mechanism. Retrieved from West African Monetary Agency: http://amao-wama.org/en/publications/review-of-ecowas-exchange-ratemechanism/

Yartey, E. (2015, June 17). West Africa's Single Currency Reliant on Economic Growth. Retrieved from African Review: http://www.africanreview.com/finance/economy/west-africa-s-single-currencyreliant-on-economic-growth

Zach, O., (2014). The importance of money. Retrieved from http://www.returnofkings.com/36650/the-importance-of-money 